\title{
PROSPEK KOTA AMBON SEBAGAI AIKON KOTA MULTIKULTURAL (PELUANG dan TANTANGAN)
}

\author{
Hakis \\ Dosen Institut Agama Islam Negeri Ambon \\ *) Email : hakisusman@gmail.com
}

\begin{abstract}
Multicultural is an interesting thing to be studied because every region and even everyone is different understanding of multiculturalism but it is sunnatullah to acknowledge its existence. But different apply multiculturalism with each other. Basically, the people of Ambon city have accepted multicultural with characteristics that differ with other people or with other cities in Indonesia. The most interesting thing in the multicultural community of Ambon city is about migrants or immigrant communities. For the people of Maluku and the people of Ambon city they are of the view that any immigrant society is still always stamped with immigrant istlah even though have children grandchild living in Ambon Maluku.
\end{abstract}

Keywords: Multiculturalism, typology, equality, cultural assimilation

\section{Pendahuluan}

Multikulturalisme adalah istilah yang digunakan untuk menjelaskan pandangan tentang ragam kehidupan di dunia, ataupun kebijakan kebudayaan yang menekankan tentang penerimaan terhadap realitas keberagaman, dan berbagai macam budaya (multikultural) yang ada dalam kehidupan masyarakat menyangkut nilainilai, sistem, budaya, kebiasaan, dan politik yang mereka anut. Multikulturalisme dapat juga dipahamni sebagai pandangan dunia yang kemudian diwujudkan dalam kesadaran politik. ${ }^{1}$

\footnotetext{
${ }^{1}$ Azyumardi Azra, (2007). "Pancasila dan Identitas Nasional Indonesia: Perspektif Multikulturalisme”. Dalam Restorasi Pancasila: Mendamaikan Politik Identitas dan Modernitas. (Bogor: Brighten Press. Jakarta: Rineka Cipta), h. 15.
}

Multikulturalisme mencakup gagasan, cara pandang, kebijakan, penyikapan dan tindakan, oleh masyarakat suatu negara, yang majemuk dari segi etnis, budaya, agama dan sebagainya, namun mempunyai cita-cita untuk mengembangkan semangat kebangssan yang sama dan mempunyai kebanggaan untuk mempertahankan kemajemukan tersebut.

Masyarakat Indonesia merupakan masyarakat dengan tingkat keanekaragaman yang sangat kompleks, dengan berbagai keanekaragaman tersebut, masyarakat kita dikenal dengan istilah masyarakat multikultural. ${ }^{2}$ Bila kita mengenal masyarakat sebagai sekelompok manusia yang telah cukup lama

\footnotetext{
${ }^{2}$ Adam Kuper \& Jessica Kuper. (2000). Ensiklopedi Ilmu-ilmu Sosial. Buku Satu: Accelerator-Lyotard. Terj. (Jakarta: PT. RajaGrafindo Persada), h. 23
} 
hidup dan bekerja sama, sehingga mampu mengorganisasikan dirinya sebagai satu kesatuan sosial dengan batas-batas tertentu, maka konsep masyarakat tersebut jika digabungkan dengan multikultural memiliki makna yang luas untuk dapat mengerti apa sebenarnya masyarakat multikultural itu.

Model masyarakat multikultural ini sebenarnya telah digunakan sebagai acuan oleh para pendiri bangsa Indonesia dalam mendesain kebudayaan bangsa, sebagaimana yang terungkap dalam penjelasan Pasal 32 UUD 1945, yang berbunyi "Kebudayaan bangsa (Indonesia) adalah puncak-puncak kebudayaan di daerah". ${ }^{3}$ Dalam model masyarakat multikultural ini, sebuah masyarakat dilihat mempunyai sebuah kebudayaan yang berlaku umum dalam masyarakat tersebut, yang coraknya seperti sebuah mozaik. Di dalam mozaik tercakup semua kebudayaan dari masyarakat-masyarakat yang lebih kecil yang membentuk terwujudnya masyarakat yang lebih besar.

Pada dasarnya, multikulturalisme yang terbentuk di Indonesia merupakan akibat dari kondisi sosio-kultural maupun geografis yang begitu beragam dan luas. Menurut kondisi geografis, Indonesia memiliki banyak pulau di mana setiap pulau tersebut dihuni oleh

\footnotetext{
${ }^{3}$ Budi Hardiman, (2003). "Pengantar: Belajar dari Politik Multikukturlisme", dalam Kewargaan Multikultural. Edlina Hafmini Eddin (penerj.), (Jakarta: Pustaka LP3ES Indonesia). h.47
}

sekelompok manusia yang membentuk suatu masyarakat. Dari masyarakat tersebut terbentuklah sebuah kebudayaan mengenai masyarakat itu sendiri. Tentu saja hal ini berimbas pada keberadaan kebudayaan yang sangat banyak dan beraneka ragam.

Masyarakat multikultural ini harus dipahami dan memaknai dalam konteks masa kini dan masa depan yang harus terus ditanamkan. Masyarakat multikultural dengan semboyan Bhineka Tunggal Ika adalah salah satu dari empat pilar kehidupan bernegara yakni Pancasila, Undang-Undang dasar Negara Republik Indonesia Tahun 1945, NKRI dan Bhineka Tunggal Ika. Pancasila adalah falsafah dan dasar negara yang menjadi landasan ideal bangsa Indonesia. UUD 1945 adalah landasarn konstitusional yang mendasari penyelenggaraan kehidupan, bermasyarakat, berbangsa dan bernegara. NKRI adalah pemersatu bangsa dan Bhineka Tunggal Ika adalah perekat persatuan dalam untaian kemajemukan. ${ }^{4}$

Akhir-akhir ini, intensitas dan ekstensitas konflik sosial di tengah-tengah masyarakat terasa kian meningkat. Terutama konflik sosial yang bersifat horisontal, yakni konflik yang berkembang di antara anggota masyarakat, meskipun tidak menutup kemungkinan

\footnotetext{
${ }^{4}$ Marsudi Noorsalim, M. Nurkhoiron, Ridwan AlMakassary (ed.) (2007). Hak Minoritas, Multikulturalisme dan Dilema Negara Bangsa. (Jakarta: The Interseksi Foundation), h. 58
} 
timbulnya konflik berdimensi vertikal, yakni antara masyarakat dan negara. Konflik sosial dalam masyarakat merupakan proses interaksi yang alamiah. Hanya saja, persoalannya menjadi lain jika konflik sosial yang berkembang dalam masyarakat tidak lagi menjadi sesuatu yang positif, tetapi berubah menjadi destruktif bahkan anarkis. Itulah yang banyak kita jumpai di dalam era reformasi ini yang sangat memperihatinkan.

Di era demokratisasi yang mengagungkan keterbukaan, sejumlah konflik sosial dalam masyarakat telah berubah menjadi destruktif bahkan cenderung anarkhis. Kasus Ambon, Poso, Maluku, GAM di Aceh, Papua, dan berbagai kasus yang menyulut kepada konflik yang lebih besar dan berbahaya. Konflik sosial berbau SARA (agama) ini tidak boleh dianggap remeh dan harus segera diatasi secara proporsional agar tidak menciptakan disintergrasi bangsa. Apakah fenomena konflik sosial ini merupakan peristiwa yang bersifat insidental dengan motif tertentu dan kepentingan sesaat, ataukah justru merupakan budaya dalam masyarakat yang bersifat laten. Realitas empiris ini juga menunjukkan kepada kita bahwa masih ada problem yang mendasar yang belum terselesaikan. Ketidakadilan masyarakat semakin terasa manakala hidup makin sulit, pekerjaan susah didapat oleh sebagian masyarakat yang menimbulkan kemiskinan, sementara ada masyarakat yang hidup lebih dari berkecukupan, menimbulkan kecemburuan sosial.

Konflik sosial Ambon tahun 1999-2004 merupakan pelajaran terpenting bagi bangsa Indonesia terutama anak negeri Maluku terkhusus kota Ambon. Realitas multikultural pada masyarakat kota Ambon sesungguhnya masih banyak problem yang mendasar yang perlu mendapat perhatian khusus dan masih perlu digali untuk menemukan akar-akar pemecahannya. Melalui tulisan ini penulis akan memaparkan tentang prospek kota Ambon sebagai ikon kota multicultural (peluang dan tantangan).

\section{Pembahasan}

\section{Kota Ambon Sebagai Kota Multikultural}

Peluang untuk menjadikan kota Ambon sebagai kota multikultul itu karena adanya rasa jenuh dan kesadaran warga setelah terjadi konflik yang hanya mengisahkan penderiaan yang berkepanjangan. Jika Ambon bisa menjadi City of Music, maka seiring waktu, Ambon dapat menjadi City of Multikulture. Ambon memiliki kearifan lokal khas yang tidak dimiliki daerahdaerah lainnya di Indonesia, "Budaya Pela dan Gandong, Ungkapan Sagu Salempeng Dipatah Dua, Potong Dikuku Rasa didaging, Hidop Ade deng Kaka, Laeng Sayang sayang laeng, Salam Sarani”, merupakan sebuah ungkapan yang 
timbul dari hati orang Maluku. Hanya di Maluku, Umat Islam membantu Umat Kristen dalam pembangunan gereja, seperti yang dilakukan Gedung Gereja Imanuel Galala Hative Kecil, dibongkar dan dibantu oleh gandong mereka dari Hitu. Bahkan Pembangunan Gereja di salah satu sektor di Lateri, dibantu oleh Pela mereka dari Desa Mamala. Begitu pun sebaliknya. Bahkan, ada tiga desa yang memiliki Gandong, sebut saja, misalnya Tamilouw (Islam), Hutumuri (Kristen) dan Siri Sori (Perpaduan warganya Bergama Islam dan Kristen) selalu mengadakan panas pela atau panas gandong, yang bertujuan mengeratkan hubungan persaudaraan antara ade deng kaka yang berbeda agama. Bahkan di Maluku, ada marga-marga yang sama, seperti Thenu, Wakanno, Wattimena dan lain sebagainya, beragama Islam dan Kristen. Dan ini sebagai bentuk pendukung bahwa Ambon layak sebagai City of Multiculture.

Selanjutnya gubernur Maluku (Said Assagaf) telah mencanangkan bahwa Ambon akan menjadi miniature laboratorium kerukunan umat beragama di dunia itu artinya bahwa kota Ambon sudah dikenal dengan multi agama, multi suku, multi bahasa, multi ras karena itu prospek dan peluang kota Ambon dalam membentuk masyarakat multikultural telah memiliki banyak faktor pendukung. Adapun faktor pendukung yang lain di antaranya faktor agama bahwa di Ambon antara Islam dan Kristen secara kuantitas hampir berimbang jumlahnya ditambah dengan agama lain seperti katolik, hindu. budha dan lain sebagainya.

Namun bisa juga menjadi penghambat jika kemudian faktor-faktor pendukung itu tidak dikelolah dengan baik. Jika dikelolah dengan baik maka ini menjadi kekuatan pendukung besar dengan tingkat keragaman budaya yang sangat besar, suku, agama demikian juga bahasa. Oleh karena itu bisa menjadi miniature dari Indonesia secara umum, dan kota yang semakin menjunjung tinggi nilai-nilai keragaman, nilai perbedaan yang dilatari oleh suku, etnis, bahasa, budaya dan ras itu.

Contoh lain misalnya kota Ambon sebagai miniature kota multikultural palin sederhana kehidupan di pasar tradisional Batu Merah dan Mardika Ambon, di pasar itu kehidupan yang sangat multikultural yang hampir semua etnis dapat hidup berdampingan misalnya dari Buton, Bugis, Makassar, Jawa, Padang dan lain-lain yang ada umumnya mereka beasimilasi dengan baik. Kemudian di kampus IAIN Ambon juga sangat multikultural yang mempunya visi misi dalam bingkai multicultural, cuma yang harus dilakukan di IAIN Ambon adalah mengamalkan simbol-simbol dan sistem masyarakat multicultural.

Selanjutnya prospek kota Ambon sudah didukung dengan masyarakat yang sangat mejemuk maka sinergisitas antara kepentingan 
yang berbeda-beda itu harus dilakukan. Misalnya orang yang asli (penduduk adat) dan penduduk yang menganggap dirinya sebagai pendatang itu harus disenergikan. Tidak bisa kemudian mengklain bahwa mereka ini harus didiskriminasikan dari yang lain dalam suatu persoalan dan ini harus diperhitungkan tidak bisa dibiarkan dan inilah kemudian tugas pemerintah untuk menjabarkan persoalan kepentingankepentingan tersebut sehingga kota Ambon itu adalah kota yang betul-betul menjadi miniature kota multikultural di Indonesia yang harus diterima apa adanya. Dengan demikian maka kota Ambon akan menjadi kota yang baik kota yang terhindar dari konflik-konflik kepentingan. Namun pemerintah juga sering menjadi penghambat lebih memihak kepada kepentingan-kepentingan kelompok tertentu (memihak kepada penduduk asli) dan mereka tidak mencoba untuk netral.

Setiap orang yang ada di republik ini tidak berdoa untuk dilahirkan di tempat tertentu, mereka tidak berdoa untuk menjadi suku apa, mereka tidak berdoa untuk menjadi agama apa ketika mereka itu dilahirkan di dunia artinya mereka ini adalah kodratnya, pemberian dari tuhan kepada seluruh umat manusia, dalam Alquran juga jelas Allah berfirman menciptakan manusia itu bersuku-suku berbangsa-bangsa untuk saling mengenal antara satu dengan yang lain artinya perbedaan itu boleh-boleh saja dan itu harus dihargai, dihormati sebagai ciptaan dari sang pengcipta. ketika ini terjadi kemudian pemerintah tidak memihak dan menetapkan hakhak itu berdasarkan porsi hukum Tetapi selama porsi itu kemudian ada keberpihakan kepada komunitas tertentu ini akan jadi persoalan, dan menjadi sorotan utama bahwa pendatang tidak berlaku hukum adat, mereka pendatang beretnis yang berbeda dengan mereka (penduduk asli) selalu saja disebut sebagai pendatang dan bisa saja mereka diusir dan lain sebagainya. Inilah yang tidak kita harapkan terjadi di Maluku khususnya di Ambon ketika ingin menjadikan kota Ambon sebagai miniature kota multiultural di Indonesia yang menjunjung tinggi keragaman dalam masyarakat. Yang harus ada muncul di Maluku adalah indahnya perbedaan itu pelangi itu indah karena adanya perbedaan warna, ada yang merah, ada kuning, ada yang biru itu disebut pelangi. Ombak di laut ketika ia tenang itu tidak indah akan tatapi ketika ada gel ombang warna-warni itu menunjukkan ke indahan demikian juga bahwa perbedaan itu tapi indah yang salah adalah ketika tidak menghargai perbedaan itu. Bukankah Indonsesia ini merupakan satu tanah air yang kemudian dibunyikan dalam semboyang kita adalah Binneka Tunggal Ika (berbeda-beda tatapi tetap satu), jika sekarang orang menyebut etnis A, etnis B, dan etnis lainya yang kemudian didiskriminasi maka tidak wajar, tidak indah di 
negeri ini yang disebut negara yang berbedabeda tetapi tetap satu. Apabila itu terjadi maka ia merupakan pelanggaran atas hak-hak masyarakat yang beretnis lain.

Jadi harapan kota Ambon sebagai ikon kota multikultural penerimaan itu harus tinggi, pendidikan multikulturalisme harus aplikasikan, diberikan lebih kongkrit dijelskan oleh pemerintah disosialisasikan kepada seluruh masyarakat sehingga masyarakat sadar bahwa kita ini berbagai etnis dari suku manapun tetap kita adalah satu yaitu Maluku yang dibungkus dengan negara kesatuan Republik Indonesia. Dan jika Maluku tidak menyadari ha itu akan akan menjadi bom waktu kalau masing-masing mengklain mereka punya hak, tidak akan bekembang sampai kapan pun ketika klaim hakhak itu dilakukan oleh generasi muda Maluku, generasi muda Maluku hari ini perlu dicerdaskan, perlu dilakukan revolusi mental mereka bahwa perbedaan diterima apa adanya bukan ada apanya.

Prospek kota Ambon untuk di dijadikan kota multikultural membuka ruang bagi sukusuku lain yang ada di Maluku, karena kota Ambon ini adalah milik kita semua orang Maluku jangan ada sekat di antara warga siapa yang ingin berbuat untuk kota Ambon itu sah-sah saja asalkan tidak keluar dari koridor atau aturanaturan seperti pela dan gandong, orang basaudara, Maluku satu darah. Orang-orang
Maluku hari ini harus tertaman dalam jiwa masing-masing generasi muda rasa memiliki.

Menurut Informan yang memberikan imput pada penulisan artikel ini mengatakan prospek kota Ambon menjadi kota multikutural, harus melalui diskusi-diskusi panjang, seminar yang berkaitan dengan konsep kehidupan multikulturalisme selalu menjadi bahan pembicaraan, bahan diskusi dan lain-lain dalam berbagai acara dan moment. Akan tetapi untuk mewujudkan semua itu pasti ada tantangan pasti juga ada hal menjadi hambatan namun sejauh ini saya lihat pemerintah kota Ambon belajar dari pengalaman hidup yang kelam dan menjadi sejarah kelam masa lalu dan mencoba membuka tabir kembali untuk lebih maju dan lebih baik kedepan. Maka yang terpenting dalam sebuah moment selalu dingatkan akan pahitnya sejarah hitam itu yang pernah terjadi di Maluku sebagai motifasi pada generasi muda bahwa jangan pernah itu terjadi lagi maka perayaan Hari Ulang Tahun (HUT) kota Ambon selalu menjadi perhatian sejarah hitam itu dan mengajak untuk melupakan semua itu dengan penguatan parade dari berbagai budaya masyarakat yang ada di Kota Ambon, kota yang heterogen yang terdiri atas beberapa suku, etnis dan budaya. Untuk ke depannya selalu ada iven-iven yang menampilkan berbagai macam kultur budaya, baik itu tari-tarian, ciri lagu-lagu daerah, pakaian adat daerah selalu ditampilkan untuk memeberi 
semangat pada generasi muda Maluku ke depan. Implementasi wujud kongkrit itu menjadi hal yang baik bilamana dikuatkan dicontohkan di kota Ambon dalam berbagai parade budaya dari daerah masing-masing. ${ }^{5}$

Kemudian faktor pendukungnya yang lain adalah pemerintah haus bisa memediasi masyarakat sehingga sekat-sekat menjadi penafsiran dari pada masyarakat atau kelompok tertentu itu sehingga identitas ini bisa dihilangkan jadi saya kira fasilitas-fasilitas pemerintah harus yang diatur lewat peraturan nasional maupun peraturan daerah sehingga kaitannya dengan masyarakat multikultural ini bisa menyesuaikan dengan perilaku di daerah itu. Dalam kaitanya dengan hambtan itu soal fasilitas saja kalau umpamanya fasilitas itu dimiliki baik fisik maupun non fisik saya kira tidak ada hambatan kalau fasilitas itu ada disiapkan oleh pemerintah atau masyarakat sendiri bisa saja agar supaya menghilangkan stigma-stigma itu bisa terwujud, jadi kuncinya ada di pemerintah atau lembaga-lembaga lain yang bisa mengadakan pembauran dalam masyarakat di kota Ambon.

Selanjutnya prospek kota Ambon menjadi kota multicultural yang masyarakatnya multikulturalisme harus bekerja keras dari berbagai aspek baik itu pemerintah, swasta ataupun masyarakat. Jika kota Ambon ini ingin

\footnotetext{
${ }^{5}$ Hasil wawancara pada wawancara, Ambon 3 Oktober 2017
}

dijadikan sebagai kota percontohan, sebagai laboratorium multicultural. Namun yang jadi masalah besar adalah ketika dari masyarakatnya sendiri tidak memahami multikultur tidak bisa beradabtasi pada lingkungan di mana ia berada, di mana ia bermukim, maka hal itu tidak akan terjadi. Akan tetapi jika mereka semua pahan arti masyarakat multikultur pasti terbuka jalan untuk menuju hal yang lebih baik. Dan ini pekerjaan besar bagi pemerintah untuk menghapus skatskat itu dan mengsosialisasikan kepada anakanak adat yang hidupnya pas-pasan karena factor kemalasan misalnya lalu kemudian ingin dengan seenaknya mengambil hasil usaha orang lain tanpa mau di ajak kompromi. Maka ketika semuanya itu tidak ditemukan lagi di kota Ambon maka kota Ambon bisa saja menjadi miniature kota multicultural di Indonesia.

\section{Tantangan kota Ambon sebagai kota multikultural}

Tantangan kota Ambon sebagai kota multikultural beragam pendapat dari kalangan masyarakat hal ini dikemukakannya dengan mengatakan keragu-raguannya tentang prospek kota Ambon menjadi kota multikultural dengan alasan bahwa masyarakat kota Ambon pada kenyataanya sudah beragam namun untuk mengakui hak-hak meraka (masyarakat urban) pada sebahagian besarnya belum memberikan ha-hak atas mereka. Masyarakat asli kota Ambon 
sebahagian masih menyimpan curiga pada masyarakat pendatang, masih terjadi diskriminasi pada masyarakat pendatang tersebut. Masih belum memberi tempat jika ada perwakilanperwakilan rakyat misalnya DPR atau DRPD dan lain sebagainya.

Selanjtnya pendapat yang ektrim mengatakan bahwa masyarakat kota Ambon belum dan tidak bisa dikatakan masyarakat multilultural selama masih terjadi segradasi penduduk berdasarkan agamanya, itu artinya merka belum bisa menerima kenyataan bahwa keragaman itu adalah sebuah anugrah yang patut kita terima apa adanya. Belum ada jaminan keamanan jika orang Islam membuat rumah pada komunitas yang beragama Kristen begitu pun sebaliknya sebagaimana sebelum konflik tahun 1999 terjadi.

Tantangan masyarakat kota Ambon berikutnya adalah ketika berbicara tentang masyarakat urban yang selalu dicap sebagai masyarakat pendatang walaupun sesungguhnya nenek moyang mereka sudah berabad menetap di Ambon akan tetapi anak cucu mereka tetap saja dikatakan sebagai masyarakat urban atau masyarakat pendatang.

Pada masyarakat kota Ambon istilah "pendatang" dikenal bagi penduduk migran, pengklasifikasian anak negeri dengan istilah pendatang itu adalah warisan dari penjajahan
Belanda dengan politik pecah belah. Akan tetapi pendatang tetap mendapat tempat pada warga kota Ambon terbukti di bagaian timur dan selatan kota Ambon terdapat perkampunganperkampung pendatang (suku Buton) hidup berdampingan dengan masyarakat Ambon walaupun berbeda Agama. Namun karena adanya konflik yang mengatasnamakan agama maka kelompok-kelompok pendatang tersebut kembali bergabung sesuai dengan komunitas agamanya masing-masing. ${ }^{6}$

Istilah pendatang bagi warga kota Ambon adalah panggilan khusus bagi warga imigran baik yang tinggal lama maupun yang baru saja tinggal bedomisili di kota Ambon. Dan istilah itu sudah sangat familiar bagi warga kota Ambon namun kadang memberi image buruk pada penduduk asli maupun penduduk imigran.

Jika dilihat pada konteks saat ini, jujur diakui, ada sebagian masyarakat pendatang yang belum mendapat tempat dan ada yang sudah, setelah mereka tergusur akibat konflik sosial. ada beberapa lokasi di Ambon, yang dulunya mereka menetap dan beranakcucu seperti di Lateri, mereka tidak kembali lagi, sehingga lokasi rumah mereka pun dijual kepada masyarakat lainnya (yang ikut tergusur didaerahnya). Namun, ada pula yang kembali mendapat tempat. Seperti umat Islam di Latta yang telah kembali

\footnotetext{
${ }^{6}$ Hasil wawancara pada penelitian, Ambon 11 September 2017
} 
ke Latta dan umat Kristen Nania yang telah menempati di Nania pula. ${ }^{7}$

Masyarakat Ambon belum sepenuhnya "terbuka", terbuka jika masyarakatnya menganut paham agama yang sama. Orang beragama Kristen terbuka jika sesama Bergama Kristen demikian juga Islam, tapi belum terbuka sepenuhnya antara orang yang beragama Kristen dengan orang yang beragama Islam. Pembauran bisa saja terjadi di tempat-tempat umum seperti Lapangan Merdeka Ambon, pasar mardika, atau tempat lainnya akan tetapi belum terbuka sepenuhnya.

Namun pemerintah juga sering menjadi penghambat lebih memihak kepada kepentingan-kepentingan kelompok tertentu (memihak kepada penduduk asli) dan mereka tidak mencoba untuk netral. Dalam situasi tertentu misalnya kalau di pemerintahan desa (bapak raja) misalnya harus ada soa-soa atau DPD-DPD namun memihak kepada kepentingan-kepentingan kepada masyarakat yang sekultur dengan mereka, seagama dengan mereka sedangkan masyarakat asli atau pendatang yang tidak sesuku dengan mereka termarjinalkan, didiskriminasi. Inilah hambatan yang menjadi utama, harapan saya adalah mestinya ini perlu dilakukan dengan sebaikbaiknya sehingga dengan demikian berbagai

\footnotetext{
Nopember 2017
}

kepentingan bisa berjalan dengan baik berjalan dengan aman semua itu tidak menganggap asli dan pendatang tetapi semua adalah masyarakat Maluku yang perlu dihormati, di hargai keberadaan.

\section{Kesimpulan}

Kota Ambon ke depan basa saja di jadikan ikon miniatur kota multikultural di Indonesia akan tetapi hal yang paling sulit untuk mencapai itu adalah segregasi wilayah berdasarkan agama. Yang perlu di kaji kemudian adalah bagaimana tingkat keamanan jika mereka kembali ketempat asalnya seperti halnya sebelum konflik tahun 1999 hidup berdampingan tanpa mengenal agama sebagaimana kota-kota yang lain di Indonesia. Namun pemerintah provinsi Maluku dan kota Ambon senangtiasa berusaha mengembalikan citra kota Ambon sebagai miniature kota multicultural di Indoensia dengan berbagai macam usaha dan selalu mengsosialisakan kepada masyarakar dalam berbagai iven-iven penting dalan kegiatankegiatan di Maluku.

Harapan kota Ambon sebagai ikon kota multikultural penerimaan itu harus tinggi, pendidikan multikulturalisme harus aplikasikan, diberikan lebih kongkrit dijelskan oleh pemerintah disosialisasikan kepada seluruh masyarakat sehingga masyarakat sadar bahwa 
kita ini berbagai etnis dari suku manapun tetap kita adalah satu yaitu Maluku yang dibungkus dengan negara kesatuan Republik Indonesia

Hal yang menarik juga dapat penulis simpulkan bahwa istilah "pendatang" bagi suku imigran yang datang ke Maluku demikian juga kota Ambon selalu ditandangkan pada dirinya walaupun ia tinggal di Maluku sudah berpuluh tahun bahkan sudah 3-5 generasi pun masih disebut dengan pendatang. Akibatnya ada hakhak yang sejatinya ia dapatkan tapi karena ia adalah pendatang maka itu kemudian dianulir contohnya kepemilikan tanah. Warga imigran hanya berhak menggarap tanah tersebut tanpa bisa dimiliki sepenuhnya.

\section{DAFTAR PUSTAKA}

Al-Makassary, Marsudi Noorsalim, M. Nurkhoiron, Ridwan Al-Makassary (ed.) Hak Minoritas, Multikulturalisme dan Dilema Negara Bangsa. (Jakarta: The Interseksi Foundation, 2007

Arikunto, Suharsimi, Prosedur Penelitian, Suatu Pendekatan Praktek, Jakarta: Reneka Cipta, 1991

Azra, Azyumardi Azra, Pancasila dan Identitas Nasional Indonesia: Perspektif Multikulturalisme”. Dalam Restorasi Pancasila: Mendamaikan Politik Identitas dan Modernitas. Bogor:
Brighten Press. Jakarta: Rineka Cipta, 2007 Identitas dan Krisis Budaya: Membangun Multikulturalisme Indonesia. 2007 , http://www.kongresbud.budpar.go.id/58 \%20ayyumardi\%20azra.htm

Creswell JW., Qualitative Inquiry and Research Design; Choosing Among Five Traditions, Londong: Sage Publications, 1998

Hardiman, Budi, Pengantar: Belajar dari Politik Multikukturlisme", dalam Kewargaan Multikultural. Edlina Hafmini Eddin (penerj.), Jakarta: Pustaka LP3ES Indonesia, 2003

Heywood, Andrew, Political Ideologies (4th Edition). Palgrave: McMillan, 2007

Kuper. Adam Kuper \& Jessica, Ensiklopedi Ilmu-ilmu Sosial. Buku Satu: AcceleratorLyotard. Terj. Jakarta: PT. RajaGrafindo Persada, 2000

Kymlicka, Will Kymlicka, Kewargaan Multikultural. Jakarta : LP3ES. 2002

Lubis, Akhyar Yusuf, Dekonstruksi Epistemologi Modern. Jakarta: Pustaka Indonesia Satu 2006

Mahfud, Choirul, Pendidikan Multikultural, Yogyakarta : Pustaka Pelajar, 2006 
Okin, Susan Moller, Feminism and Multiculturalism: Some Tensions, \| Ethics 108, 1998
Taylor, C. et all , Multiculturalism, Examining the politics of Recognition. United Kingdom: Princeton University Press, 1994

Parekh, Bikhu, Rethinking Multiculturalism.

Harvard. 2001 dalam Azyumardi Azra, Identitas dan Krisis Budaya: Membangun Multikulturalisme Indonesia. 2007, http://www.kongresbud.budpar.go.id/58 \%20ayyumardi\%20azra.htm

Phillips, Anne, Multiculturalism Without Culture, Princeton: Princeton University Press, 2007

Suparlan, Parsudi, Dari Masyarakat Majemuk Menuju Masyarakat Multikultural, Jakarta: YPKIK, 2008

Suparlan, Parsudi, Menuju Masyarakat Indonesia yang Multikultural\|. Keynote Address Simposium III Internasional Jurnal ANTROPOLOGI INDONESIA, Universitas Udayana, Denpasar, Bali, 1619 Juli 2002

Suseno, Franz Magnis, Berebut Jiwa BangsaDialog Persaudaraan dan Perdamaian, Jakarta: Kompas, 2005

Suyata, Pendidikan Multikultural dan Reintegrasi Nasional: Implikasi Kebijakan, Pidato Pengukuhan Guru besar. Yogyakarta: UNY, 2001 